\title{
Komposisi Kimia, Karakteristik Fisik, dan Organoleptik Sosis Ayam dengan Penambahan Karagenan dan Transglutaminase
}

\author{
A. Ismanto ${ }^{1 *}$, D. P. Lestyanto ${ }^{2}$, M. I. Haris, Y. Erwanto ${ }^{2}$ \\ ${ }^{1}$ Program Studi Peternakan, Fakultas Pertanian, Universitas Mulawarman, Samarinda, Indonesia 75123 \\ ${ }^{2}$ Program Studi Ilmu dan Industri Peternakan Fakultas Peternakan Universitas Gadjah Mada, Yogyakarta, \\ Indonesia 55281
}

\begin{abstract}
ABSTRAK
Penelitian ini bertujuan untuk mengetahui pengaruh penambahan karagenan dan transglutaminase terhadap komposisi kimia, kualitas fisik, dan karekteristik organoleptik sosis ayam. Rancangan percobaan yang digunakan dalam penelitian adalan rancangan RAL (Rancangan Acak Lengkap) terdiri dari 4 perlakuan yaitu P0 (sosis dengan penambahan karagenan $3 \%$ dan tanpa penambahan transglutaminase), P1 (sosis + karagenan $3 \%+$ transglutaminase $2 \mathrm{ml}$ ), P2 (sosis + karagenan $3 \%+$ transglutaminase $3 \mathrm{ml}$ ) dan P3 (sosis + karagenan $3 \%$ + transglutaminase $4 \mathrm{ml}$ ) dengan masing-masing perlakuan diulang sebanyak 6 ulangan. Variabel yang diamati komposisi kimia (kadar air, kadar protein, kadar lemak dan kadar abu), kualitas fisik (pH, susut masak dan Daya Ikat Air) dan kualitas organoleptik (warna, aroma, tekstur dan rasa). Data komposisi kimia dan kualitas fisik dianalisis menggunakan ANOVA, dan diuji lanjut menggunakan Least Significant Different (LSD). Data kualitas organoleptik dianalisis menggunakan Uji Sensoris Kruskal dan Wallis. Hasil penelitian menunjukkan sosis daging ayam dengan penambahan karagenan dan transglutaminase pada level yang berbeda mempengaruhi kadar air, kadar protein, dan kadar lemak, kadar abu. Sosis daging ayam dengan penambahan karagenan dan transglutaminase pada level yang berbeda berpengaruh pada nilai $\mathrm{pH}$, susut masak, dan daya ikat air Sosis daging ayam dengan penambahan karagenan dan transglutaminase pada level yang berbeda memberikan pengaruh pada kesukaan panelis pada semua parameter (warna, hedonic aroma, hedonic tekstur, rasa) tetapi tidak mempengaruhi penilaian panelis pada mutu hedoniknya. Penambahan transglutaminase sampai dengan $3 \mathrm{ml}$ menyebabkan terjadinya penurunan kualitas kimia tetapi meningkatkan kesukaan panelis pada parameter rasa.
\end{abstract}

Kata kunci: Sosis daging ayam, Transglutaminase, Karagenan, Kualitas kimia, Kualitas fisik, Organoleptik

\section{Chemical Composition, Physical Characteristics, and Organoleptics of Chicken Sausage with Addition of Carrageenan and Transglutaminase}

\begin{abstract}
This study aims to determine the effect of the addition of carrageenan and transglutaminase on the chemical composition, physical quality, and organoleptic characteristics of chicken sausage. The experimental design used in the study was CRD (Completely Randomized Design) consisting 4 treatments, namely PO (sausages with the addition of carrageenan $3 \%$ and without the addition of transglutaminase), P1 (sausages with addition of carrageenan 3\% + addition of $2 \mathrm{ml}$ transglutaminase), P2 (sausage sausages with $3 \%$ carrageenan added $+3 \mathrm{ml}$ transglutaminase addition and P3 (sausage with $3 \%$ carrageenan addition $+4 \mathrm{ml}$ transglutaminase addition) with six replications each treatment. The variables observed were chemical composition (water content, protein content, fat content, and ash content), physical quality (pH, cooking losses and water binding capacity) and organoleptic quality (colour, aroma, texture and taste). Data on chemical composition and physical quality were analyzed using ANOVA and further tested using Least Significant Different (LSD). Organoleptic quality data were analyzed using the Kruskal and Wallis Sensory Tests. The results showed chicken sausage with the addition of carrageenan and transglutaminase at different levels affected the water content, protein content, and fat content, ash content. Chicken meat sausages with the addition of carrageenan and transglutaminase at different levels affect the pH value, cooking losses, and water holding capacity. Chicken meat sausages with the addition of carrageenan and transglutaminase enzymes at different levels have an influence on panellists preference for all parameters (colour, hedonic aroma, hedonic texture, taste) but do not affect panellists assessment of their hedonic quality. Addition of transglutaminase up to the level of $3 \mathrm{ml}$ causes a decrease in chemical quality but increases the panelists' preference for taste parameters.
\end{abstract}

Keywords: Chicken sausage, Transglutaminase, Carrageenan, Chemical quality test, Physical quality, Organoleptic

\section{PENDAHULUAN}

Daging merupakan salah satu sumber pangan yang penting bagi manusia karena daging merupakan penghasil protein terbesar dibandingkan dengan produk pertanian yang lain. Sundari et al. (2015) menyatakan bahwa kadar protein daging ayam: $18,71 \%$, protein

*Penulis Korespondensi: Arif Ismanto

Alamat: Fakultas Pertanian Universitas Mulawarman, Kampus Gn.

Kelua, Jl Pasir Belengkong POBOX 1040 Samarinda, Kalimantan

Timur 75123

Email: arifismanto9@gmail. tempe, $18,44 \%$, dan protein pada tahu sebesar 13,84 $\%$. Daging ayam merupakan salah satu pilihan favorit masyarakat, yang terlihat dari data konsumsi daging ayam yang mengalami peningkatan. Data tahun 2015 konsumsi daging ayam sebesar 54,7 ton kemudian meningkat menjadi 55,9 ton, 61,7 ton, 63 ton dan 64,3 ton berturut-turut pada 2016, 2017, 2018 dan 2019 (Dinas Peternakan dan Kesehatan Hewan Provinsi Kalimantan Timur, 2019).

Salah satu olahan daging ayam adalah sosis. Sosis merupakan produk emulsi daging yang ditambahkan 
bahan pengisi, bahan pengikat dan bumbu-bumbu untuk meningkatkan flavor dan daya terima. Ada beberapa karakteristik yang harus dipenuhi untuk dapat dikatakan sosis yang berkualitas memiliki memiliki tekstur kenyal, cooking loss rendah, Daya Ikat Air (DIA) yang tinggi sehingga memiliki juiceness yang baik, daya irisnya baik, dan memiliki rasa yang dapat diterima oleh konsumen.

Beberapa dekade terakhir, produk pangan diproduksi tidak hanya untuk memenuhi kebutuhan nutrisi, akan tetapi lebih kepada pemenuhan aspek kesehatan. Serat pangan dapat mempengaruhi fungsi gastrointestinal dan proses sistem tubuh yang lain. Meskipun dapat disediakan melalui suplementasi, sangat dianjurkan bahwa serat pangan tersebut sebaiknya diperoleh melalui konsumsi alami, seperti sereal, buah-buahan, sayuran atau kacang-kacangan (Galisteo et al., 2008). Salah satu sumber serat dari lautan yang potensinya cukup besar adalah karagenan.

Kappa karagenan (k-karagenan) merupakan salah satu jenis karagenan yang dapat berfungsi sebagai serat pangan yang mempunyai potensi sebagai bahan pengikat sekaligus pembentuk tekstur pada sosis yang belum banyak dimanfaatkan. Setelah terbentuk gel, kargenan ini akan resisten terhadap degradasi. Secara umum karagenan dapat digunakan dalam industri makanan sebagai stabilisator (pengatur keseimbangan), thickener (bahan pengental), pembentuk gel, pengemulsi dan lain-lain. Berdasarkan penelitian sebelumnya, penggunaan karagenan pada level 3\% diketahui memiliki sifat fungsional yang baik, akan tetapi sosis ayam dengan karagenan level tersebut memiliki tekstur yang kasar (Ismanto, 2013). Langkah yang bisa dilakukan untuk mengatasi permasalahan tersebut adalah dengan menambahkan bahan yang dapat meningkatkan stabilitas produk selama pemasakan sehingga tekstur produk lebih baik. Penambahan Transglutaminase ke dalam produk merupakan salah satu alternatif yang dapat ditempuh. Basaran et al. (2010) menyatakan bahwa Transglutaminase (TGase) dapat menginisiasi pembentukan ikatan kovalen antara glutamin dan lisin dalam protein. Menambahkan MTGase dapat meningkatkan stabilitas termal protein daging, memberikan sifat yang diinginkan untuk produk restrukturisasi selama proses pemanasan. Penelitian ini dilakukan untuk mengetahui pengaruh penambahan karagenan dan transglutaminase terhadap komposisi kimia, kualitas fisik dan henonik serta mutu hedonik sosis ayam.

\section{MATERI DAN METODE}

\section{Bahn dan Alat}

Bahan yang digunakan dalam penelitian ini adalah daging ayam (bagian dada dan paha atas), garam, bawang putih, tepung tapioka, es batu, lada putih, mentega, karagenan jenis kappa-karagenan, microbial transglutaminase dipurifikasi dari Streptoverticillum mobaraense produksi Ajinomoto.co. Ltd, aquades, dan selongsong sosis. Alat yang digunakan dalam penelitian ini adalah mesin penggiling daging, timbangan digital, kompor, panci, baskom, sendok, sarung tangan, pisau, plastik klip, gunting, spidol, uji kimia (cawan aluminium, oven), uji fisik (plat kaca, kertas saring, kertas millimeter block, beban seberat 35 $\mathrm{kg}$, gelas ukur, pH meter HM 7J TOA, plastik mika), uji organoleptik (alat tulis, kertas, kuisioner).

\section{Penyiapan Sosis dan Penambahan Enzim Transglutaminase}

Penyiapan sosis dilakukan menurut metode (Yang et al., 2007) dengan penyesuaian yaitu pada proses stuffing yang dilakukan secara manual. Sosis yang digunakan untuk pengujian tiap perlakuan adalah seberat $150 \mathrm{~g}$, dengan komposisi penyusun sosis yaitu: daging $108 \mathrm{~g} \mathrm{(74 \% );} \mathrm{binder} \mathrm{berupa} \mathrm{albumen} \mathrm{telur} \mathrm{ayam}$ $7,5 \mathrm{~g}(3 \%)$, lemak 4,5 g (3\%), filler berupa tepung terigu (5\%), bumbu 5,1 g (3,4\%), garam 2,5 g $(1,67$ $\%)$, gula $1,9 \mathrm{~g}(1,3 \%)$, dan es batu $(8,67 \%)$. Tahapan pertama pembuatan sosis diawali dengan penggilingan daging ayam, setelah itu dilakukan pencampuran bumbu dan karagenan. Transglutaminase sebanyak 1 mg, selanjutnya dicampurkan ke dalam $20 \mathrm{mM}$ larutan $\mathrm{NaCl}$ sebanyak $20 \mathrm{ml}$, kemudian dimasukkan ke dalam adonan sosis. Pada sosis P0 tidak dilakukan penambahan transglutaminase, pada P1 dilakukan penambahan transglutaminase sebanyak $2 \mathrm{ml}$, pada P2 dilakukan penambahan transglutaminase sebanyak 3 $\mathrm{ml}$ dan pada P4 dilakukan penambahan transglutaminase sebanyak $4 \mathrm{ml}$. Selanjutnya adonan sosis dimasukan ke dalam casing, lalu didiamkan dengan suhu $4^{\circ} \mathrm{C}$ selama 24 jam, setelah itu dikukus selama 30 menit pada suhu $100^{\circ} \mathrm{C}$.

\section{Pengujian Kualitas Kimia}

Pengujian kualitas kimia yang dilakukan meliputi pengujian kadar air, kadar abu dilakukan dengan metode gravimetrik dan kadar protein menggunakan Kjeldahl. Kualitas kimia sosis dianalisis menurut metode Association of Official Analytical Chemist (AOAC) (1995).

\section{Pengujian Kualitas Fisik}

\section{Pengukuran pH Sosis}

Nilai $\mathrm{pH}$ diuji dengan menggunakan elektroda glass $\mathrm{pH}$ meter mengikuti metode yang telah dilakukan oleh Tan et al. (2007).

\section{Susut Masak Sosis}

Perhitungan susut masak dengan melihat kehilangan berat selama pemasakan dalam satuan \% dan ditentukan dengan kombinasi pada masing-masing pengulangan menurut metode (Boles \& Swan, 1996).

\section{Daya Ikat Air (DIA)}

Pengujian daya ikat air dilakukan menurut metode Hamm (1972). Pengujian daya ikat air sosis diawali dengan menyiapkan sampel seberat $0,3 \mathrm{~g}$. Sosis $0,3 \mathrm{~g}$ 
tersebut diletakkan di antara dua kertas saring jenis whatman, lalu di press di alat corperpress hingga tekanan $35 \mathrm{~kg} / \mathrm{m} 2$ selama 5 menit. Setelah sosis dalam tumpukan kertas saring sudah menjadi cetakan seperti lempengan ukur luasan tersebut menggunakan planimeter. Kadar air Sosis dilakukan dengan cara timbang sosis sebanyak $5 \mathrm{~g}$, lalu masukkan dalam cawan porselen dan timbang kembali. Cawan porselin yang berisi sampel dikeringkan dalam oven dengan suhu $105^{\circ} \mathrm{C}$ selama 16 jam sampai diperoleh berat kering konstan. Cawan porselen yang berisi sampel selanjutnya didinginkan dalam desikatorkemudian ditimbang.

Rumus luas area basah daging:

Luas Area Basah = Luas Area Luar - Luas Area Dalam

Setelah mendapatkan luas area basah, ukur $\mathrm{mgH}_{2} \mathrm{O}$ yang terkandung:

$\mathrm{mgH}_{2} \mathrm{O}=\frac{\text { Luas area basah }(\mathrm{cm})}{0,0948}-8,0$

Keterangan: $0,0948=$ konstanta rumus $\mathrm{mgH}_{2} \mathrm{O}$

Rumus kadar air daging:

kadar air $=\frac{[B-(C-A)]}{B} \times 100 \%$

Keterangan: $\quad A=$ Berat cawan

$\mathrm{B}=$ Berat sampel segar

$\mathrm{C}=$ Berat cawan+sampel setelah oven

Menghitung daya ikat air (DIA) dalam daging:

$($ DIA $)=$ Kadar Air Tetap - Kadar Air Bebas

$$
\begin{aligned}
\text { Daya ikat air }= & \text { kadar air }(\%)-\left(\frac{\mathrm{mgH}_{2} \mathrm{O}}{300}\right) \\
& \times 100 \%
\end{aligned}
$$

\section{Pengujian Hedonik dan Mutu Hedonik Sosis}

Panelis merupakan panelis semi terlatih, terdiri dari mahasiswa dan staf Fakultas Pertanian Universitas Mulawarman dengan jenis kelamin yang tidak ditentukan perbandingannya. Perekrutan, seleksi dan training dilakukan berdasarkan prosedur evaluasi sensoris (Murray and Delahunty, 2001). Lima belas panelis diseleksi dari 25 panelis potensial menggunakan tes identifikasi rasa dasar. Sampel sosis dimasak dalam oven sebagaimana dijelaskan sebelumnya, kemudian dipotong-potong dan disajikan dalam keadaan hangat. Skor penilaian mutu hedonik warna (1-5: coklat - putih), aroma (1-5: sangat beraroma daging - sangat tidak beraroma daging), tekstur (1-5: kasar - halus) dan rasa (1-5: sangat pahit sangat tidak pahit). Penilaian uji hedonik untuk semua parameter (1-5: sangat tidak suka - sangat suka). Panelis dipisahkan menjadi dua kelompok untuk menghindari kelelahan, etiap kelompok terdiri dari empat orang, masing-masing kelompok mengevaluasi setengah dari sampel.

\section{Analisis Data}

Penelitian menggunakan analisisvariansi yang disusun dalam Rancangan Acak Lengkap (RAL) dengan level transglutaminase yang terdiri dari 4 aras yaitu: tanpa penambahan transglutaminase (P0), penambahan $2 \mathrm{ml}$ transglutaminase $(\mathrm{P} 1)$, penambahan $3 \mathrm{ml}$ transglutaminase (P2), dan penambahan $4 \mathrm{ml}$ transglutaminase (P3). Data pengujian kualitas kimia dan fisik dianalisis dengan ANOVA. Apabila terdapat perbedaan tiap perlakuan dilanjutkan dengan uji Beda Nyata Terkecil (BNT) (Steel dan Torrie, 1993). Data hasil pengujian hedonik dan mutu hedonik dianalisis dengan menggunakan Kruskal Wallis.

\section{HASIL DAN PEMBAHASAN}

\section{Komposisi Kimia Sosis Ayam dengan Penambahan Karaginan dan Enzim Transglutaminase}

\section{Kadar Air}

Hasil penelitian yang telah dilakukan menunjukkan bahwa perbedaan level transglutaminase tidak mempengaruhi nilai kadar air. Kadar yang terendah terdapat pada P1 yaitu 51,83\% dan kadar air yang tertinggi terdapat pada P0 yaitu 53,50\% (Tabel 1).

Tingginya kadar air pada perlakuan P0 diduga karena jumlah tepung terigu yang ditambahkan pada formulasi pembuatan sosis lebih banyak dibandingkan dengan perlakuan yang lain. Pada penelitian ini, formulasi tepung terigu berkurang karena subtitusi dengan penambahan TGase. Sifat dari tepung secara umum adalah dapat menyerap air dengan sempurna. Cato et al. (2015) menjelaskan bahwa tepung terigu dapat mengikat air dengan sempurna dan tidak mudah terlepaskan. Dalam suatu pengolahan, tepung terigu berfungsi sebagai zat penangkap air dan menciptakan suatu karakteristik tertentu. Hal ini juga sesuai dengan

Tabel 1. Komposisi kimia sosis ayam dengan penambahan karagenan dan transglutaminase

\begin{tabular}{ccccc}
\hline \hline Perlakuan & Kadar air(\%) & Kadar protein $(\%)$ & Kadar lemak $(\%)$ & Kadar abu(\%) \\
\hline P0 & $53,50 \pm 3,16^{\mathrm{a}}$ & $18,16 \pm 2,37^{\mathrm{a}}$ & $1,51 \pm 0,05^{\mathrm{d}}$ & $2,69 \pm 0,74^{\mathrm{ns}}$ \\
P1 & $51,83 \pm 2,05^{\mathrm{c}}$ & $16,54 \pm 3,17^{\mathrm{b}}$ & $3,78 \pm 0,54^{\mathrm{c}}$ & $2,58 \pm 0,07^{\mathrm{ns}}$ \\
P2 & $52,64 \pm 2,04^{\mathrm{b}}$ & $15,40 \pm 1,13^{\mathrm{c}}$ & $5,07 \pm 0,39^{\mathrm{a}}$ & $2,59 \pm 0,12^{\mathrm{ns}}$ \\
P3 & $53,40 \pm 4,09^{\mathrm{a}}$ & $14,88 \pm 2,07^{\mathrm{d}}$ & $4,72 \pm 0,87^{\mathrm{b}}$ & $3,36 \pm 0,25^{\mathrm{ns}}$ \\
\hline
\end{tabular}

$\overline{\text { a,b,c,d }}$ Superskrip yang berbeda pada baris yang sama menunjukkan perbedaan yang nyata $(\mathrm{P}<0,05)$, ns (non signifant) $=$ berbeda tidak nyata $(\mathrm{P}>0,05) . \mathrm{P} 0=$ sosis ayam dengan penambahan $3 \%$ karaginan dan tanpa penambahan transglutaminase; $\mathrm{P} 1=$ sosis ayam dengan penambahan $3 \%$ karaginan $+2 \mathrm{ml}$ transglutaminase; $\mathrm{P} 2=$ sosis ayam dengan penambahan $3 \%$ karaginan $+3 \mathrm{ml}$ transglutaminase; sosis ayam dengan penambahan $3 \%$ karaginan $+4 \mathrm{ml}$ transglutaminase 
pernyataan Kusumaningrum et al. (2013) yang menyatakan bahwa pada tepung terigu mengandung karbohidrat berupa amilosa dan amilopektin. Amilosa dan amilopektin apabila dimasukan ke dalam air, granula patinya akan menyerap dan membengkak, sehingga dapat mempengaruhi nilai kadar air yang dihasilkan pada produk. Kadar air maksimal sosis daging menurut SNI adalah $67 \%$ (BSN, 2015). Berdasarkan hal tersebut maka hasil uji kadar air yang diperoleh dalam penelitian ini sesuai dengan standar sosis yang baik menurut SNI.

\section{Kadar Protein}

Kadar protein sosis daging ayam dengan penambahan karagenan dan enzim Transglutaminase dapat dilihat pada Tabel 1. Berdasarkan data pada Tabel 1. diketahui bahwa kadar protein yang terendah terdapat pada P3 yaitu $14,88 \%$ dan kadar protein yang tertinggi terdapat pada P0 yaitu 18,16\%. Berdasarkan data tersebut, juga dapat dilihat bahwa dari perlakuan P0 sampai dengan P3 kadar protein mengalami penurunan. Hal ini kemungkinan disebabkan adanya peningkatan kadar air pada produk sehingga persentase protein semakin rendah. Pada penelitian terdahulu yang dilakukan oleh Kawahara et al. (2017), dilakukan perlakuan penambahan enzim transglutaminase pada sosis daging ayam dan babi, hasil yang diperoleh adalah kadar protein sosis yang memperoleh perlakuan enzim transglutaminase mengalami penurunan dibanding dengan sosis tanpa perlakuan enzim transglutaminase. Protein juga berperan sebagai pengikat air produk sosis, hal ini didukung oleh Khasrad et al. (2016) Kadar protein daging yang tinggi menyebabkan meningkatnya kemampuan menahan air daging sehingga menurunkan kandungan air bebas, dan begitu pula sebaliknya. Standar minimal kandungan protein pada sosis ayam menurut BSN (2015) adalah $13 \%$. Hal ini dapat diartikan bahwa kandungan protein hasil penelitian berada pada kategori yang baik.

\section{Kadar Lemak}

Kadar lemak sosis ayam dengan penambahan karaginan dan variasitransglutaminase dapat dilihat pada Tabel 1. Berdasarkan data pada Tabel 1 kadar lemak yang terendah terdapat pada P0 yaitu $1,51 \%$ dan kadar lemak yang tertinggi terdapat pada P2 yaitu 5,07 $\%$. Menurut BSN (2015) standar maksimal kadar lemak pada sosis ayam yaitu $20 \%$, sehingga kadar lemak sosis ayam yang sudah diuji pada Tabel 1 masih dalam standar yang normal. Amany et al. (2012) menyatakan bahwa semakin tinggi temperatur pemasakan akan menyebabkan suatu produk menjadi semakin porous dan emulsinya dapat pecah, hal ini menyebabkan kadar air dan kadar lemak menurun. Lengkey et al. (2016) berpendapat kadar lemak sosis perlu diperhatikan, karena kadar lemak yang tinggi dapat menjadi masalah

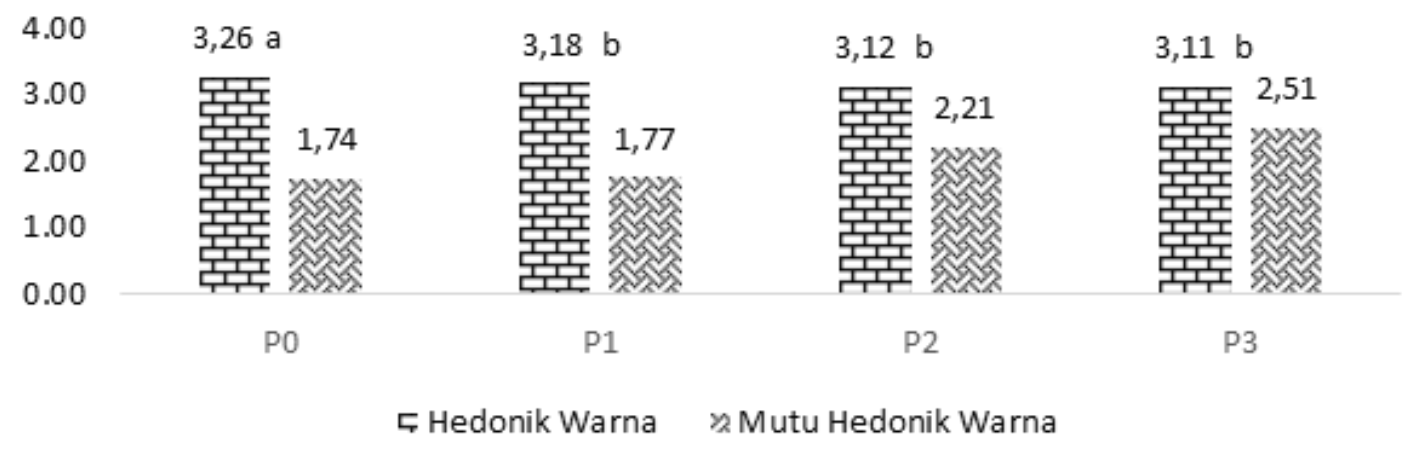

Gambar 1. Hasil pengujian hedonik dan mutu hedonik warna sosis

Keterangan:

1. ${ }^{\mathrm{a}, \mathrm{b}, \mathrm{c}}$ superskrip pada perlakuan yang berbeda pada mutu hedonik warna menunjukan berbeda nyata $(\mathrm{P}<0,05)$

2. Skor hedonik warna : 1-5 (sangat tidak suka - sangat suka); Skor mutu hedonik warna : 1 -5 (sangat coklat - putih)

3. $\mathrm{P} 0=$ sosis ayam dengan penambahan $3 \%$ karaginan dan tanpa penambahan transglutaminase $; \mathrm{P} 1=$ sosis ayam dengan penambahan $3 \%$ karaginan $+2 \mathrm{ml}$ transglutaminase; $\mathrm{P} 2=$ sosis ayam dengan penambahan $3 \%$ karaginan $+3 \mathrm{ml}$ transglutaminase; sosis ayam dengan penambahan 3\% karaginan $+4 \mathrm{ml}$ transglutaminase

Tabel 2. Kualitas fisik sosis ayam dengan penambahan karagenan dan transglutaminase

\begin{tabular}{cccc}
\hline \hline Perlakuan & Rata-rata nilai $\mathrm{pH}$ & Rata-rata susut masak $(\%)$ & Rata-rata DIA (\%) \\
\hline P0 & $5,7 \pm 0,04$ & $4,24 \pm 1,10$ & $58,68 \pm 2,60$ \\
P1 & $5,7 \pm 0,03$ & $3,10 \pm 0,78$ & $60,05 \pm 1,30$ \\
P2 & $5,7 \pm 0,01$ & $4,52 \pm 1,19$ & $58,85 \pm 1,78$ \\
P2 & $5,7 \pm 0,01$ & $4,52 \pm 1,19$ & $58,85 \pm 1,78$ \\
P3 & $5,7 \pm 0,02$ & $3,96 \pm 0,77$ & $60,72 \pm 1,52$ \\
\hline
\end{tabular}

Keterangan: $\mathrm{P} 0=$ sosis ayam dengan penambahan $3 \%$ karaginan dan tanpa penambahan transglutaminase; $\mathrm{P} 1=$ sosis ayam dengan penambahan $3 \%$ karaginan $+2 \mathrm{ml}$ transglutaminase; $\mathrm{P} 2=$ sosis ayam dengan penambahan $3 \%$ karaginan +3 ml transglutaminase; sosis ayam dengan penambahan $3 \%$ karaginan $+4 \mathrm{ml}$ transglutaminase 
bagi konsumen. Selain itu, apabila kadar lemak terlalu tinggi maka tampilan sosis akan menjadi kurang baik karena lemak dalam emulsi sosis akan terpisah.

\section{Kadar Abu}

Hasil pengujian kadar abu yang telah di lakukan diketahui kadar abu berkisar antara 2,68 \% sampai 3,36 $\%$. Kadar abu sosis daging ayam yang terendah terdapat pada P1 yaitu 2,58\% dan kadar abu yang tertinggi terdapat pada P3 yaitu 3,36\% (Tabel 1). Menurut BSN (2015) standar kadar abu maksimal sosis daging ayam adalah 3,0 \%, maka dari hasil penelitian ini hanya P3 yang melebihi standar kadar abu. Hal ini kemungkinan disebabkan konsentrasi transglutaminase yang mencegah produk kehilangan bahan organik selama pemanasan. Kadar abu merupakan campuran antara komponen anorganik atau mineral yang terdapat pada suatu bahan pangan (Setyaningrum, 2013).

\section{Sifat Fisik Sosis Ayam dengan Penambahan Karaginan dan Enzim Transglutaminase}

\section{Nilai pH}

Nilai $\mathrm{pH}$ sosis ayam dengan penambahan karagenan dan enzim transglutaminase dengan level yang berbeda dapat dilihat pada Tabel 2. Hasil analisis statistik menunjukkan bahwa perbedaan level transglutaminase tidak mempengaruhi nilai $\mathrm{pH}$. Ratarata nilai $\mathrm{pH}$ yang diperoleh pada setiap perlakuan $\mathrm{P}$, P1, P2 dan P3 yaitu 5,7, sedangkan dalam penelitian Lengkey et al. (2016) yang menggunakan pemberian margarin rata-rata nilai $\mathrm{pH}$ yaitu 5,6. Menurut Sofiana (2012) nilai $\mathrm{pH}$ yang diharapkan dalam penelitian daging adalah 5,1 sampai dengan 6,1. Nilai pH juga mempengaruhi lama waktu simpan produk olahan peternakan karena nilai $\mathrm{pH}$ berhubungan terhadap tingkat pertumbuhan mikroorganisme yang dapat merusak produk, hal ini didukung oleh pendapat Saka (2016) yang menyatakan parameter $\mathrm{pH}$ dalam produk memegang kunci penting untuk kualitas karena nilai $\mathrm{pH}$ berpengaruh terhadap pertumbuhan mikroorganisme, perubahan temperatur dan struktur kimia suatu senyawa dalam kandungan produk.

\section{Susut Masak}

Hasil analisis statistik yang telah dilakukan menunjukkan bahwa penambahan karagenan dan enzim transglutaminase dengan level yang berbeda tidak berpengaruh nyata terhadap nilai susut masak. Nilai susut masak pada setiap perlakuan memiliki nilai P0 (4,24 \%), P1 (3,10\%), P2 (4,52\%) dan P3 (3,96\%). Penelitian Ismanto et al. (2016) yang menggunakan penambahan karagenan nilai susut masak berkisar antara 1,76 -3,92\%. Nilai susut masak pada penelitian ini menunjukkan hasil yang lebih tinggi dari penelitian tersebut. Besarnya nilai susut masak pada penelitian ini diduga dipengaruhi oleh lebih rendahnya dosis karagenan yang digunakan. Ismanto et al. (2016) berpendapat sosis dengan penambahan karagenan akan membentuk gel sehingga eksudasi cairan dari dalam peroduk akan terhambat, hal ini dapat terlihat pada penambahan karagenan sebanyak $6 \%$ nilai susut masak sebesar $1,96 \%$, sedangkan dengan penggunaan dosis sebesar $3 \%$ nilai susut masak menjadi $2,17 \%$, Sofiana (2012) berpendapat bahwa DIA dan $\mathrm{pH}$ daging berhubungan dengan susut masak (cooking loss). Bila DIA rendah maka cooking loss akan tinggi. Hal ini juga terjadi pada penelitian ini dimana pada P3 yang nilai DIA paling rendah yaitu $3,96 \pm 0,77$ mempunyai nilai cooking loss yang tinggi yaitu $60,72 \pm 1,52$.

\section{Daya Ikat Air}

Hasil analisis perhitungan statistik menunjukan bahwa penambahan karagenan dan enzim transglutaminase pada level yang berbeda tidak

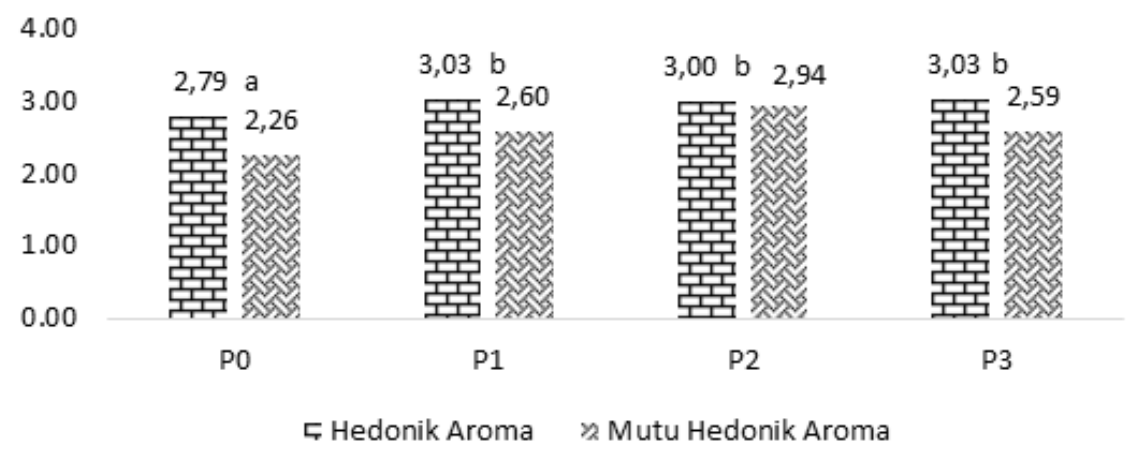

Gambar 2. Hasil pengujian hedonik dan mutu hedonik aroma sosis

Keterangan:

1. ${ }^{\mathrm{a}, \mathrm{b}, \mathrm{c}}$ superskrip pada perlakuan yang berbeda pada mutu hedonik warna menunjukan berbeda nyata $(\mathrm{P}<0,05)$

2. Skor hedonik warna : 1-5 (sangat tidak suka - sangat suka), Skor mutu hedonik warna : 1 -5 (sangat beraroma daging tidak beraroma daging)

3. $\mathrm{PO}=$ sosis ayam dengan penambahan $3 \%$ karaginan dan tanpa penambahan transglutaminase; $\mathrm{P} 1=$ sosis ayam dengan penambahan $3 \%$ karaginan $+2 \mathrm{ml}$ transglutaminase; $\mathrm{P} 2=$ sosis ayam dengan penambahan $3 \%$ karaginan $+3 \mathrm{ml}$ transglutaminase; sosis ayam dengan penambahan 3\% karaginan $+4 \mathrm{ml}$ transglutaminase 
berpengaruh nyata terhadap nilai daya ikat air sosis ayam $(\mathrm{P}>0,05)$. Nilai daya ikat air sosis ayam dengan penambahan karagenan dan enzim transglutaminase dengan level yang berbeda pada penelitian ini berkisar antara 58,68 - 60,72\%, tetapi pada penelitian Ismanto et al. (2016) yang menggunakan penambahan karagenan nilai daya ikat airnya berkisar antara 22-23 $32,67 \%$, sehingga pada penelitian DIA mempunyai nilai lebih tinggi. DIA selain ditentukan oleh jenis daging juga ditentukan oleh fungsi otot, $\mathrm{pH}$, dan komposisi kimia daging serta bahan-bahan yang ditambahkan dalam daging lumat pada kondisi pH lebih tinggi atau lebih rendah dari $\mathrm{pH}$ titik isoelektik proteinprotein daging $(5,0-5,1)$ daya ikat air akan meningkat karena pada $\mathrm{pH}$ yang lebih tinggi atau lebih rendah dari $\mathrm{pH}$ titik isoelektik protein daging mengakibatkan molekul- molekul daging yang bermuatan akan saling tolak menolak sehingga menimbulkan ruang-ruang koson g bagi molekul-molekul air (Soeparno, 2005).

\section{Uji Hedonik dan Mutu Hedonik Sosis Ayam dengan Penambahan Karaginan dan Enzim Transglutaminase}

\section{Warna Sosis Daging Ayam}

Hasil analisis statistik pengujian organoleptik skala hedonik warna sosis menunjukkan hasil yang tidak berbeda nyata $(\mathrm{P}>0,05)$, tetapi pada pengujian mutu hedonik warna menunjukkan hasil yang berbeda nyata $(\mathrm{P}<0,05)($ Gambar 1$)$. Secara umum panelis lebih menyukai warna sosis ayam tanpa penambahan transglutaminase yaitu sosis ayam dengan warna putih kecoklatan. Nilai kesukaan hedonik warna tertinggi pada perlakuan P0 $(3,26)$. Nilai kesukaan hedonik warna terendah pada perlakuan P3 $(3,11)$. Kemungkinan hal ini disebabkan oleh kandungan lemak pada sosis ayam pada sosis dengan penambahan transglutaminase yang lebih tinggi daripada sosis ayam tanpapenambahan transglutaminase. Interaksi antara polisakarida dan protein seperti disebutkan oleh $\mathrm{Al}$ Hasan (2017) akan mencegah komponen yang ada di dalam produk khususnya komponen yang peka terhadap panas salah satunya adalah lemak.

\section{Aroma Sosis Daging Ayam}

Hasil analisis statistik hedonik aroma yang sudah dilakukan menunjukkan hasil yang tidak berbeda nyata $(\mathrm{P}>0,05)$ sedangkan pada pengujian organoleptik skala mutu hedonik aroma menunjukkan hasil yang berbeda nyata $(\mathrm{P}<0,05)($ Gambar 2$)$. Nilai kesukaan tertinggi pada perlakuan P2 yaitu 2,94 dan nilai kesukaan terendah pada perlakuan P0 yaitu 2,26.

Panelis lebih menyukai aroma sosis ayam yang diberi penambahan transglutaminase dibandingkan sosis ayam tanpa penambahan transglutaminase. Hal ini kemungkinan disebabkan sosis dengan penambahan transglutaminase lebih tidak beraroma daging dibandingkan control. Protein dan lemak yang terikat oleh transglutaminase meyebabkan precursor aroma daging tidak banyak keluar selama pemasakan.

Dalam industri pangan, uji aroma sangat penting karena dapat memberikan hasil penilaian penerimaan konsumen terhadap produk yang dihasilkan dengan cepat. Aroma produk olahan sosis yang disukai adalah aroma daging. Hasil penelitian ini sejalan dengan pendapat dari Rauf et al. (2015) yang menyatakan bahwa aroma produk olahan daging dapat dipengaruhi oleh bahan-bahan yang ditambahkan selama

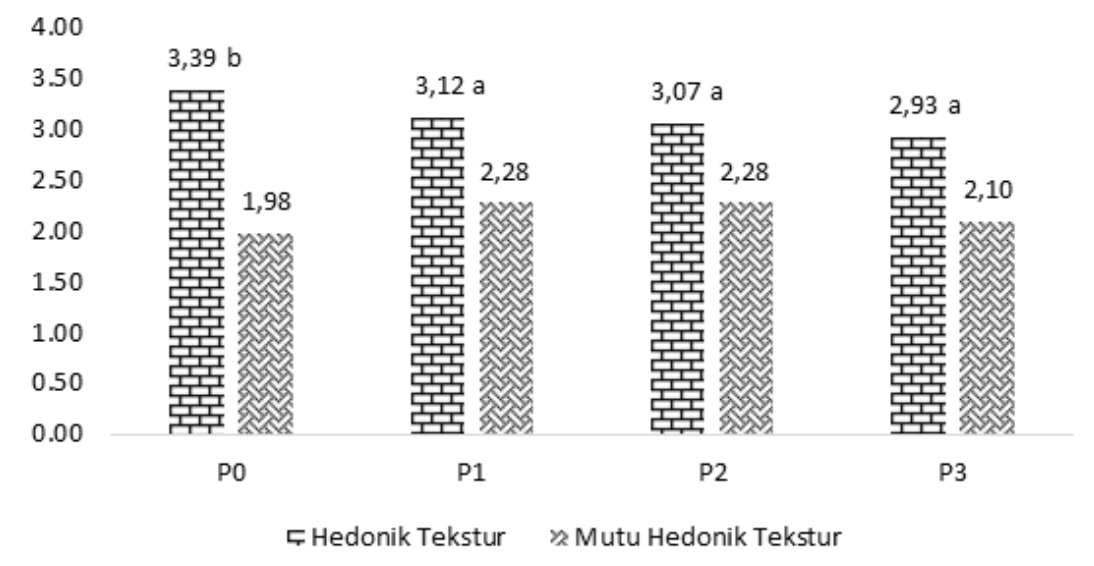

Gambar 3. Hasil pengujian hedonik dan mutu hedonik tekstur sosis

Keterangan:

1. ${ }^{\mathrm{a}, \mathrm{b}, \mathrm{c}}$ superskrip pada perlakuan yang berbeda pada mutu hedonik warna menunjukan berbeda nyata $(\mathrm{P}<0,05)$

2. Skor hedonik warna : 1-5 (sangat suka - sangat tidak suka), Skor mutu hedonik warna : 1 -5 (kasar - halus)

3. $\mathrm{P} 0=$ sosis ayam dengan penambahan $3 \%$ karaginan dan tanpa penambahan transglutaminase; $\mathrm{P} 1=$ sosis ayam dengan penambahan $3 \%$ karaginan $+2 \mathrm{ml}$ transglutaminase; $\mathrm{P} 2=$ sosis ayam dengan penambahan $3 \%$ karaginan $+3 \mathrm{ml}$ transglutaminase; sosis ayam dengan penambahan $3 \%$ karaginan $+4 \mathrm{ml}$ transglutaminase 
pembuatan dan pemasakan produk olahan daging. Pada penelitian ini seluruh bahan yang ditambahkan selain daging adalah karagenan dan enzim transglutaminase (Widjanarko et al., 2012).

\section{Tektur Sosis Daging Ayam}

Hasil analisis statistik hedonik tekstur sosis menunjukkan hasil yang tidak berbeda nyata $(\mathrm{P}>0,05)$ sedangkan pada pengujian mutu hedonik tekstur menunjukkan hasil yang berbeda nyata $(\mathrm{P}<0,05)$ (Gambar 3). Nilai kesukaan tertinggi pada perlakuan P1 dan P2 $(2,28)$. Nilai kesukaan terendah pada perlakuan P0 (1,98). Panelis lebih menyukai tekstur sosis dengan penmabahan transglutaminase dibandingkan sosis tanpa penambahan transglutaminase. Rata- rata panelis menyatakan bahwa tekstur dengan penambahan transglutaminase lebih halus.

Tekstur merupakan salah satu aspek yang dapat mempengaruhi penilaian konsumen terhadap produk. Tekstur akan memberikan informasi tentang kelembutan makanan, bentuk permukaan pada makanan serta keadaan makanan (kering, basah dan lembab).Menurut Ruiz-Capillas et al. (2012), tekstur ditentukan oleh komposisi bahan penyusun sosis, kondisi homogenisasi dan proses pengolahannya. Produk olahan sosis ayam memiliki tekstur lembut dan halus.

\section{Rasa Sosis Daging Ayam}

Hasil analisis statistik hedonik rasa sosis menunjukkan hasil yang tidak berbeda nyata $(\mathrm{P}>0,05)$ pengujianmutu hedonik rasa menunjukkan hasil yang berbeda nyata $(\mathrm{P}<0,05)$ (Gambar 4). Rasa yang paling disukai oleh panelis adalah sosis ayam dengan penambahan transglutaminase sebanyak $3 \mathrm{ml}(\mathrm{P} 2)$.

Rasa merupakan sebuah reaksi kimia dari gabungan berbagai bahan makanan dan menciptakan sesuatu rasa baru yang dirasakan oleh lidah. Atribut ini banyak ditentukan oleh formulasi yang digunakan dan tidak dipengaruhi pengolahan (Winarno, 2008). Nilai kesukaan rasa sosis berkisar 1 - 5 (sangat tidak suka sangat suka). Nilai kesukaan tertinggi pada perlakuan P3 (2,04). Nilai kesukaan terendah pada perlakuan P0 (1,57). Hasil uji kesukaan rasa sosis terdapat pada Gambar 4. Panelis lebih condong memberikan penilaian citarasa terhadap produk olahan yang banyak mengandung daging. Menurut Purnawati et al. (2015) konsumen lebih menyukai produk olahan dengan rasa daging. Prayitno (2009) menyatakan bahwa rasa suatu bahan pangan dapat berasal dari bahan pangan itu sendiri dan bahan lain pada produk yang ditambahkan.

\section{KESIMPULAN}

1. Sosis daging ayam dengan penambahan karagenan dan enzim transglutaminase pada level yang berbeda dapat mempengaruhi kadar protein, kadar lemak, dan kadar air, semakin besar level yang diberikan akan menurunkan nilai kadar protein dan meningkatkan kadar lemak pada sosis.
2. Sosis daging ayam dengan penambahan karagenan dan enzim transglutaminase pada level yang berbeda tidak berpengaruh pada nilai $\mathrm{pH}$ dan susut masak tapi berpengaruh terhadap daya ikat air.

3. Sosis daging ayam dengan penambahan karagenan dan enzim transglutaminase pada level yang berbeda untuk kualitas organoleptik hedonik warna, tekstur, aroma, dan rasa menunjukan hasil tidak berpengaruh tetapi pada mutu hedonik warna, tekstur, aroma, dan rasa berpengaruh.

\section{UCAPAN TERIMA KASIH}

Ucapan terimakasih kami sampaikan kepada Kepala Laboratorium Teknologi Hasil Ikutan dan Lingkungan Fakultas Peternakan Universitas Gadjah Mada yang telah memberikan dukungan material penelitian.

\section{DAFTAR PUSTAKA}

AL-Hassan, A.A. and M. H. Norziah. 2017. Effect of transglutaminase induced crosslinking on the properties of starch/gelatin films. Food Packaging and Shelf Life 13: 15-19.

Amany, M., M. Basuny, M. Shaker, Arafat, Azza and AA. Ahmed. 2012. Vacuum frying: an alternative to obtain high quality potato chips and fried oil. Global Advanced Research Journal 1(2): 19-26.

AOAC. 1995. Offical Methods of Analysis. 16th ed. AOAC Int.Washington D.C.

Badan Standardisasi Nasional. 2015. Sosis: SNI 3820. Dewan Standardisasi Nasional. Jakarta.

Basaran, P., N. Basaran-Akgul and B.A. Rasco. 2010. Dielectric properties of chicken and fish muscle treated with microbial transglutaminase. Food Chemistry, 120(2): 361-370.

Boles, J.A. and J.E. Swan. 1996. Effect of postslaughter processing and freezing on the functionality of hot-boned meat from young bull. Meat Science 44: 11-18.

Dinas Peternakan dan Kesehatan Hewan Provinsi Kalimantan Timur. 2019. Buku Statistik. Dinas Peternakan dan Kesehatan Hewan Provinsi Kalimantan Timur. Samarinda

Galisteo, M., J. Duarte and A. Zarzuelo. 2008. Effects of dietary fibers on disturbances clustered in the metabolic syndrome. Journal of Nutritional Biochemistry 19(2): 71-84

Hamm, R. 1972. Kolloidchemie des Fleisches-des Wasserbindungs-vermoegendes Muskeleiweisses in Theorie und Praxis. Verlag Paul Parey. Berlin.

Ismanto, A. 2013. Pengaruh bahan pengikat (karagenan, albumen dan gelatin) dan lemak terhadap komposisi kimia, kualitas fisik dan karakteristik sensoris sosis sapi. Jurnal Teknologi Pertanian 8(2): 69-74.

Ismanto, A. dan D. Sumarna. 2016. Pengaruh penambahan karagenan dengan level yang 
berbeda terhadap komposisi kimia, kuaitas fisik, sensoris, dan mikrostruktur sosis ayam. Buletin Peternakan 40(1): 58-65.

Kawahara, S., A. Ahhmed, M. Ohta, K. Nakade and K. Muguruma. 2007. Inconsistency in the improvements of gel strength in chicken and pork sausages induced by microbial transglutaminase. Journal of Animal Science 20(8): 1285-1291.

Khasrad, A. Sarbaini, Arfai dan Rusdimansyah, 2016. Perbandingan Kualitas Kimia (Kadar Air, Kadar Protein dan Kadar Lemak) Otot Biceps Femoris pada Beberapa Bangsa Sapi. Tesis. Fakultas Peternakan. Universitas Andalas.

Kusumaningrum, M., Kusrahayu dan S. Mulyani. 2013. Pengaruh berbagai filler (bahan pengisi) terhadap kadar air, rendemen dan sifat organoleptik (warna) chicken nugget. Journal of Chemical Information and Modeling 53(9): 1689-1699.

Lengkey, H.A.W., S. Sembor, M. Garnida, D. Edianingsih, P. Nanah dan N. Balia. 2016. Pengaruh pemberian margarin terhadap sifat fisiko kimiawi dan sensoris sosis ayam petelur afkir. Jurnal Agritech 36(3): 279-285.

Murray, J.M. and C.M. Delahunty. 2001. Descriptive sensory analysis: past, present and future. Food Research International Journal (34): 461-471.

Prayitno, A.H., F. Miskiyah, A.V. Rachmawati, T.M. Baghaskoro, B.P. Gunawan dan Soeparno. 2009. Karakteristik $\beta$-Caroten dari labu kuning (Curcubita moschata). Buletin Peternakan 33(2): 111-118.

Purnawati, T.R., Y. Praptiningsih dan Sukatiningsih. 2015. Karakteristik sensoris dan fisiokimia sosis lele dumbo (Clarias gariepinus) yang dibuat dengan variasi jenis dan konsentrasi bahan pengikat. Jurnal Berkala Ilmiah Pertanian 10: 2734.

Rauf, N.H, R.S. Sulistijowati dan R.M. Harmain. 2015.
Mutu organoleptik sosis lele yang disubtitusi dengan rumput laut. Jurnal Ilmiah Perikanan dan Kelautan 3(3): 125-129.

Ruiz-Capillas, C., M. Triki, A.M. Herrero, L.R. Salas and F.J. Colmenero. 2012. Konjac gel as pork backfat replacer in dry fermented sausages: Processing and quality characteristics. Meat Science Jurnal 92(2): 144-150.

Setyaningrum, E.D. 2013. Fraksinasi dan Identifikasi Senyawa Antioksidan pada Ekstrak Etanol Daun Pacar Kuku (Lawsonia inermis L.) Secara Kolom Kromatografi. Skripsi. Program Studi Farmasi. Universitas Katolik Widya Mandala. Surabaya.

Soeparno. 2005. Ilmu dan Teknologi Daging. Gajah Mada University Press. Yogyakarta.

Sofiana, A. 2012. Penambahan tepung protein kedelai sebagai pengikat pada sosis sapi. Jurnal Ilmiah Ilmu-Ilmu Peternakan 15(1): 1-7.

Steel, R.G.D. dan J.H. Torrie. 1993. Prinsip dan Prosedur Statistika Suatu Pendekatan Biometrik. Edisi kedua. Margie Group. Jakarta

Sundari, D., Almasyhuri dan A. Lamidi. 2015. Pengaruh peroses pemasakan terhadap komposisi zat gizi bahan pangan sumber protein. Jurnal Media Litbangkes 25 (4): 235-242.

Tan, F.J., F.Y. Liao, Y.J. Jhan and D.C. Liu. 2007. Effect of replacing pork back fat with yams (Dioscoreaalata) on quality characteristics of Chinese sausage. Journal of Food Engineering 79: 858-863.

Widjanarko, B.S., E. Zubaidah dan A.M. Kusuma. 2012. Studi kualitas fisik-kimiawi dan organoleptik sosis ikan lele dumbo (C gariepinus) akibat pengaruh perebusan, pengukusan dan kombinasinya dengan pengasapan. Jurnal Teknologi Pertanian 4(3): 193-202.

Winarno, F.G. 2008. Kimia Pangan dan Gizi. MBrio Press. Bogor. 